\title{
Evaluation of 3D printing in planning, practicing, and training for endovascular lower extremity arterial interventions
}

\author{
Endovasküler alt ekstremite arteriyel girişimleri için planlama, uygulama ve eğitimde \\ $3 D$ baskının değerlendirilmesi
}

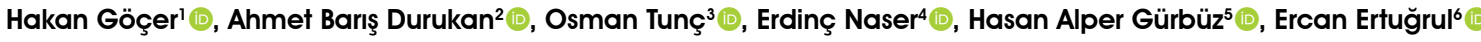 \\ Institution where the research was done: \\ Medical Park Uşak Hospital, Uşak, Turkey \\ Author Affiliations: \\ 'Department of Cardiology, Medical Park Uşak Hospital, Uşak, Turkey \\ ${ }^{2}$ Department of Cardiovascular Surgery, Medical Park Uşak Hospital, Ușak, Turkey \\ ${ }^{3}$ BTECH Company, METU Technocity, Ankara, Turkey \\ ${ }^{4}$ Department of Cardiovascular Surgery, Afyon Park Hospital, Afyon, Turkey \\ ${ }^{5}$ Department of Cardiovascular Surgery, Memorial Ankara Hospital, Ankara, Turkey \\ ${ }^{6}$ Department of Cardiology, Medical Park Izmir Hospital, Izmir, Turkey
}

\begin{abstract}
Background: In this study, we aimed to investigate the potential role of 3D-printed physical and digital anatomical models in pre-procedural planning, practice and training in lower extremity arterial interventions.

Methods: A total of 16 patients ( 9 males, 7 females; mean age: $72.1 \pm 1.5$ years; range, 69 to 75 years) who underwent superficial femoral artery balloon angioplasty between February 2016 and April 2019 were retrospectively reviewed for vascular access site preference and balloon sizing. Pre-procedural computed tomography volumetric images used for diagnosis were analyzed and modeled with 3D printing. Procedural and 3D-based data regarding the size of the balloon and deployment sites and the severity of the stenosis were compared.

Results: Measurements obtained from 3D models manually and segmentation images from software were similar $(p>0.05)$. Both were smaller than the actual size of balloons used $(\mathrm{p}<0.001)$. Stenosis severity was similar with manual and software methods and both were significantly lower than the reported quantitative angiographic measurements $(\mathrm{p}<0.001)$. Vascular access site preference was changed in five $(31.2 \%)$ patients, when the model was simulated by a non-sterile practice on 3D-printed physical models. The wire and catheter selection differed in eight patients, while practicing with models.
\end{abstract}

Conclusion: The planning and practicing of lower extremity arterial procedures with 3D models may reduce operator-dependent variables, avoid unnecessary interventions, reduce endothelial damage, and increase procedural success. The 3D-printed models may be used for educational purposes for medical professionals.

Keywords: Angioplasty, balloon, MIMICS software, peripheral arterial disease, printing, three-dimensional. $\ddot{o Z}$

Amaç: Bu çalışmada alt ekstremite arteriyel girişimlerde işlem öncesi planlama, uygulama ve eğitimde 3D baskılı fiziksel ve dijital anatomik modellerin potansiyel rolü araştırıldı.

Çalışma planı: Şubat 2016-Nisan 2019 tarihleri arasında yüzeyel femoral arter balon anjiyoplasti uygulanan toplam 16 hasta (9 erkek, 7 kadın; ort. yaş: $72.1 \pm 1.5$ yıl; dağılım, 69-75 yıl) vasküler erişim bölgesi tercihi ve balon boyutlandırma açısından retrospektif olarak incelendi. Tanı için kullanılan işlem öncesi bilgisayarlı tomografi volümetrik görüntüleri değerlendirildi ve 3D baskı ile modellendi. Balon ve yerleştirme yerlerinin büyüklüğü ve darlığın şiddetine ilişkin işlemsel ve 3D tabanlı veriler karşılaştırıldı.

Bulgular: 3D modellerden manuel olarak alınan ölçümler ve yazılımın bölümleme görüntüleri benzerdi ( $p>0.05)$. Her ikisi de, kullanılan balonların gerçek boyutundan daha küçüktü $(\mathrm{p}<0.001)$. Darlık şiddeti, manuel ve yazılım yöntemleri ile benzer olup, her ikisi de bildirilen kantitatif anjiyografik ölçümlerden anlamlı düzeyde daha düşüktü $(\mathrm{p}<0.001)$. Model 3D baskılı fiziksel modellerde steril olmayan uygulama ile simüle edildiğinde, beş hastada (\%31.2) vasküler erişim bölgesi tercihi değiştirildi. Model ile çalışırken sekiz hastada tel ve kateter seçimi farklılaştı.

Sonuç: Alt ekstremite arteriyel işlemlerinin 3D modellerle planlanması ve uygulanması operatöre bağlı değişkenleri azaltabilir, gereksiz girişimleri önleyebilir, endotel hasarını azaltabilir ve işlem başarısını artırabilir. 3D baskılı modeller tıp uzmanları için eğitim amaçlı kullanılabilir.

Anahtar sözcükler: Anjioplasti, balon, MIMICS yazılımı, periferik arter hastalığı, bask1, üç boyutlu.

Received: July 22, 2020 Accepted: September 07, 2020 Published online: January 13, 2021

Correspondence: Ahmet Barıș Durukan, MD. Medical Park Ușak Hastanesi, Kalp ve Damar Cerrahisi Bölümü, 64200 Ușak, Türkiye. Tel: +90 312 - 2536666 e-mail: barisdurukan@yahoo.com 
The value of three-dimensional (3D) printing in medical applications and practice has been recognized only in the last decade. ${ }^{[1]}$ It has been mainly employed for pre-procedural planning of complex congenital heart disease, planning and practicing of catheter-based or surgical procedures, educational purposes and, also development and testing of innovative devices. ${ }^{[2-4]}$ Our group has also recently published the role of $3 \mathrm{D}$ printing in carotid artery stenting and coronary artery bypass grafting (CABG) ${ }^{[5,6]}$ It mainly allows the operator to make accurate decisions on choice and size of material to be used in vascular procedures and pre-procedural practice in both vascular interventions and catheter-based cardiac interventions and cardiac surgery. ${ }^{[1,2,4-8]}$

For peripheral arterial interventions, imaging modalities are the gold standard for evaluation of vascular anatomy, extent and severity of disease, and type and size of material to be used. ${ }^{[9]}$ However, with current imaging technology, it is not possible to make pre-procedural practice and have an idea on the final state of the vascular site after treatment. In this study, we aimed to examine the role of 3D printing on pre-procedural detailed assessment of the anatomy and disease and determination of access site, type and size of materials to be used, and finally technical success for the purpose of sharing these models for medical professional education.

\section{PATIENTS AND METHODS}

A total of 16 patients ( 9 males, 7 females; mean age: $72.1 \pm 1.5$ years; range, 69 to 75 years) who underwent successful superficial femoral artery (SFA) interventional procedures at Medical Park Uşak Hospital, Departments of Cardiology and Cardiovascular Surgery, between February 2016 and April 2019 were retrospectively analyzed for vascular access site preference and balloon sizing. Baseline demographic and clinical characteristics of the patients were recorded. A written informed consent was obtained from each patient. The ethical approval was waived due to the study design. However, a written permission was obtained from the institution where the study was conducted. The study was conducted in accordance with the principles of the Declaration of Helsinki.

All vascular procedures were performed by the same experienced interventionist. Pre- procedural computed tomography (CT) images (Toshiba Aquilion One Vision Edition 640 slice Dynamic volume tomography; Canon Medical Systems, CA, USA) were used for diagnostic purposes. All procedures were performed by catheters and wires, which were suitable for lower extremity anatomy. The vascular access site was either femoral or popliteal artery. The Medtronic peripheral arterial drug-eluting balloons (Medtronic Inc., MN, USA) sized $6 \times 20 \mathrm{~mm}$ to $10 \times 60 \mathrm{~mm}$ were used. The selection for access site, and balloon sizing were based on interventionist's spatial perception of two-dimensional (2D) angiographic images and clinical knowledge during the procedure.

Preoperative CT images were evaluated retrospectively and were modeled with $3 \mathrm{D}$ printing where Digital Imaging and Communications in Medicine (DICOM) files on axial, coronal and sagittal plans were converted to Standard Tessellation Language (STL) files (segmentation images) by MIMICS $^{\circledR}$ Innovation Suite version 22.0 software (Materialise NV, Leuven, Belgium, CE.0120 Certification). Arterial lumen and the wall were created with data processing via manual smoothing and hollow command in design module (3-matic). The STL files were, then, exported to 3D printer (Formlabs Form 2, Formlabs Inc., MA, USA, and Laser Specifications: EN 60825-1:2007 certified) and printed using resin. The 3D models were treated with wash and cure process and detached from support points. All 3D models were prepared at the Middle East Technical University Technopark, BTECH Company facility on May 2019. Optimal balloon lengths and diameters were evaluated manually with a digital caliber on physical models and 3D printing software on digital model (Figure 1). These values were compared with the actual balloon sizes determined by the operator based on 2D angiography. The severity of SFA narrowing were calculated by both physical and digital models (Figure 1). These were compared with 2D angiographic measurements from quantitative angiography.

After evaluation of therapeutic accuracy, to gain a better understanding of spatial geometry of the lesions, practice with 3D-printed models was performed by the same interventionist under X-ray, in a non-sterile environment with different catheters, wires, and routes (Figure 2).

\section{Statistical analysis}

Statistical analysis was performed using the PASW for Windows version 17.0 software (SPSS Inc., Chicago, IL, USA). Categorical variables were expressed as number and percentages. All results, which show abnormal distribution, were expressed as the median and percentile and analysis was performed using The Friedman two-way analysis of variance (ANOVA). 

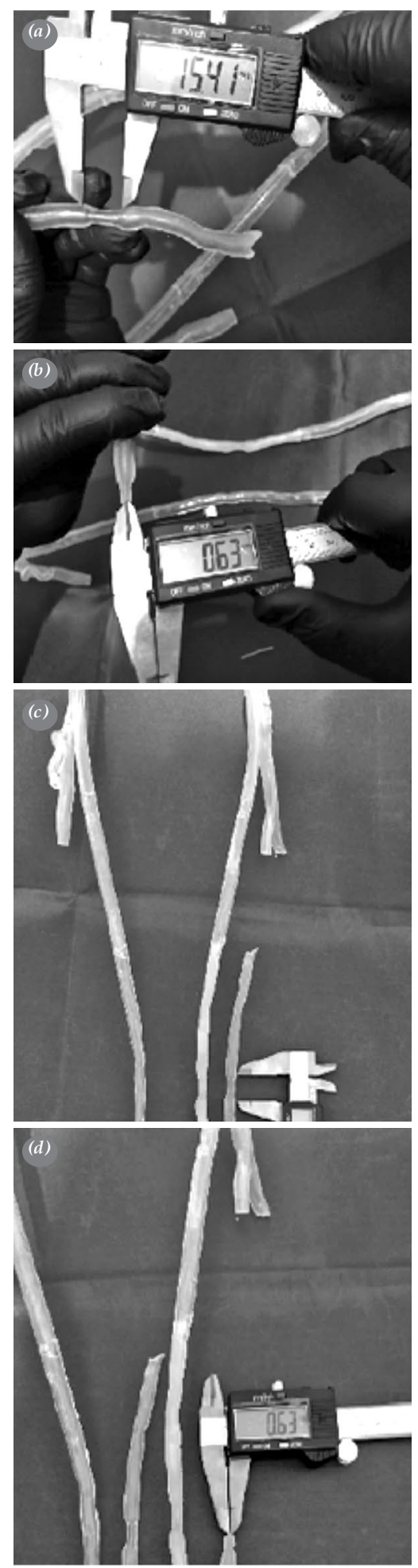

Figure 1. Manuel measurements of 3D printed physical models with digital caliper. (a) Lesion length of SFA measured with digital caliper. (b) Lesion diameter of SFA measured with digital caliper. (c) SFA lumen diameter measured with digital caliper from demounted part. (d) SFA lesion length measured with digital caliper from demounted part.

3D: Three-dimensional; SFA: Superficial femoral artery.
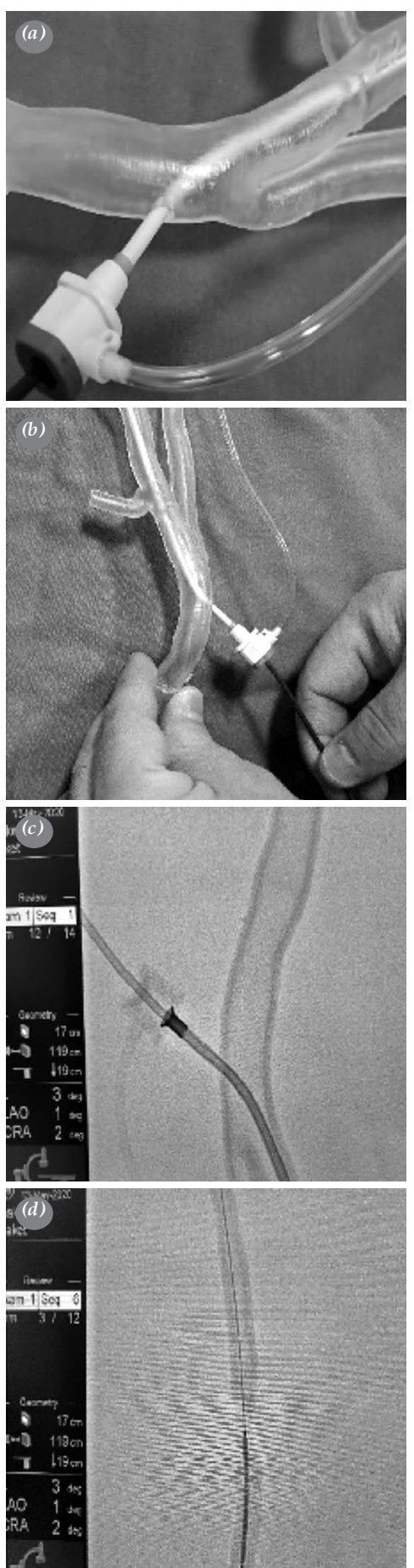

Figure 2. Manual practice with different catheters, wires on 3D physical models in both non-sterile environment and under X-ray tube. (a) SFA access site cannulation with $6 \mathrm{~F}$ sheath and guiding catheter in non-sterile environment. (b) SFA artery cannulation with guiding catheter and crossing the lesion with micro catheter in non-sterile environment. (c) Sheath and guiding catheter placement to SFA artery under X-ray in anteroposterior view. (d) Crossing the lesion with wire and balloon under angiographic guidance in anteroposterior view.

3D: Three-dimensional; SFA: Superficial femoral artery. 


\section{RESULTS}

The mean body mass index and left ventricular ejection fraction of the patients were $29.0 \pm 1.1 \mathrm{~kg} / \mathrm{m}^{2}$ and $57.1 \pm 4.0 \%$, respectively. As the access site, the ipsilateral femoral artery was preferred in 10 patients, the ipsilateral popliteal artery in one patient, and the contralateral femoral artery in five patients.

The measurements of each peripheral drug-eluting balloon diameter and length were similar for manual measurements via a digital caliper and segmentation images via measurement module of the MIMICS ${ }^{\circledR}$ software ( $p>0.05$, Tables 1 and 2). However, these measurements were lower than the actual balloon sizes (based on 2D angiography during procedure) $(p<0.001$, Tables 1 and 2). A bias toward the use of oversized balloons were detected. The estimated SFA stenosis severity (\%) were similar in both manual and software methods, but were lower than reported quantitative angiography measurements $(\mathrm{p}<0.001$, Tables 1 and 2).

All procedures were simulated in the catheter lab by the same operator on physical models under X-ray. Those simulations yielded a different access site preference in five $(31.2 \%)$ patients (three ipsilateral femoral artery access shifted to contralateral and two contralateral shifted to ipsilateral) and different sheath-catheter and wire preference in eight (50\%) patients, whereas treatment option was switched to medical therapy in one (6.2\%) patients.

\section{DISCUSSION}

The 3D printing technology has been adapted to medical applications recently for use in neurosurgery, dentistry, plastic and reconstructive surgery, cardiac

Table 1. The actual and estimated measurements of balloon size and length and stenosis severity (\%)

\begin{tabular}{|c|c|c|c|c|c|c|c|}
\hline & \multicolumn{6}{|c|}{ Measurement method } & \multirow[b]{3}{*}{$p$} \\
\hline & \multicolumn{2}{|c|}{ 3D printed models } & \multicolumn{2}{|c|}{$\begin{array}{c}\text { Preoperative 2D } \\
\text { angiography }\end{array}$} & \multicolumn{2}{|c|}{$\begin{array}{l}\text { Mimics software } \\
\text { segmentation images }\end{array}$} & \\
\hline & Median & $\begin{array}{c}25^{\text {th }} \text { and } 75^{\text {th }} \\
\text { percentiles }\end{array}$ & Median & $\begin{array}{l}25^{\text {th }} \text { and } 75^{\text {th }} \\
\text { percentiles }\end{array}$ & Median & $\begin{array}{c}25^{\text {th }} \text { and } 75^{\text {th }} \\
\text { percentiles }\end{array}$ & \\
\hline Balloon diameter $(\mathrm{mm})$ & 6 & $6-7$ & 8 & $7-8$ & 6 & $6-7$ & $\chi^{2}=25.60, p<0.001$ \\
\hline Balloon length (mm) & 40 & $40-57.5$ & 60 & $60-60$ & 45 & $40-60$ & $\chi^{2}=26.17, p<0.001$ \\
\hline Estimated stenosis (\%) & 0.75 & $0.70-0.80$ & 0.89 & $0.83-0.96$ & 0.76 & $0.73-0.80$ & $\chi^{2}=27.26, p<0.001$ \\
\hline
\end{tabular}

2D: Two-dimensional; 3D: Three-dimensional

Table 2. Comparison of manual, 2D angiographic and software methods for balloon sizing and estimation of arterial stenosis severity

\begin{tabular}{lccc}
\hline & Manual & Angiographic & Software \\
\hline SFA balloon diameter $(\mathrm{mm})$ & & & \\
$\quad$ Manual & - & & \\
Angiographic & $\mathrm{p}<0.001$ & - & - \\
$\quad$ Software & $\mathrm{NS}$ & $\mathrm{p}<0.001$ & \\
SFA balloon length (mm) & & & \\
$\quad$ Manual & - & & - \\
Angiographic & $\mathrm{p}<0.001$ & - & \\
$\quad$ Software & $\mathrm{NS}$ & $\mathrm{p}<0.001$ & \\
Estimated SFA stenosis $(\%)$ & & & \\
$\quad$ Manual & - & & - \\
Angiographic & $\mathrm{p}<0.001$ & - & - \\
Software & $\mathrm{NS}$ & $\mathrm{p}<0.001$ & - \\
\hline
\end{tabular}

SFA: Superficial femoral artery; NS: Non-Significant; 2D: Two-dimensional. 
surgery, and vascular interventional procedures. Pre-procedural planning in carotid artery stenting, ${ }^{[6]}$ endovascular aneurysm repair, ${ }^{[1]}$ atrial appendix closure, ${ }^{[8]}$ determination of cardiac valve functions ${ }^{[8]}$ preoperative planning in complex congenital cardiac surgery ${ }^{[2,10]}$ and $\mathrm{CABG}^{[5]}$ have been reported with 3D printing technology. The common purpose of the studies is pre-procedural/operative planning, optimization of the materials used, and optimization of the procedure and aid in clinical practice. In congenital heart surgery, 3D technology allows to identify defects and aid in determining patch sizes and configuration of the new pathways to be created. ${ }^{[2,10]}$ In CABG, it allows optimization of the length of the saphenous vein graft to be used. ${ }^{[5]}$ For carotid stenting, it allows pre-determination of stent sizes. ${ }^{[6]}$ In the current research era, 3D models have been used as scaffolds for angiogenesis. ${ }^{[11]}$ In the literature, there is no study regarding its application in clinical practice. Based on our experience in carotid artery disease ${ }^{[6]}$ we developed a setup for practicing in these interventions and made comparison of access site and balloon sizing preference, as well as stenosis severity estimation.

Based on our experience, 3D printing allows a wide perceptive to understand lower extremity arterial spatial geometry and pathological anatomy. Access site preference, catheter selection, and balloon sizing have been optimized in terms of pre-procedural planning. The method has provided pre-procedural practicing repeatedly in a non-sterile environment via 3D-printed physical models. Moreover, the balloon sizes would be smaller, if based on software or 3D-printed models rather than the actual angiographic measurements. The vascular access site preference and wires used also differ, when based on software and 3D-printed models. The procedure time can be shortened with an increase in the success rates. However, we observe in the clinical settings that there is resistance to this modality probably from the increased costs and operator prejudice. Of note, the technology is still in its infancy and mostly dominated by engineering rather than medicine. Physicians are not accustomed to the technology itself as in imaging modalities. It mandates a collaborative approach between engineers and physicians. Daily trend stems gathering data from imaging modalities and medical decision-making based on clinical evidence. The most prominent feature of 3D technology is that it allows physical models with different physical properties, thereby, resulting in mimicking more realistic tissue architecture and pathological anatomy. ${ }^{[5,6]}$ Physical hollow transparent models give an unlimited practicing opportunity and increase expertise. In a similar fashion, previously, 3D models have been used for educational purposes to rehearse insertion of guidewires and stents together, giving the sense of human arterial texture. ${ }^{[12]}$ It was concluded that 3D models were superior to conventional teaching models for anatomical teaching and femoral vessel access training. ${ }^{[13]}$

However, physical models that increase cost are not mandatory, since software-created digital models of lower extremity arterial tree can also give accurate estimation of stenosis severity, accurate data on vascular access site, and balloon sizing, as documented in our study. It is possible to make 3D measurements during segmentation step with command modules of software. ${ }^{[1,8]}$ This software enables us to make more accurate surface-to-surface, and intra- and extraluminal virtual measurements without printing physical models. ${ }^{[8,10]}$

It has been well documented that the balloon and stent sizing are of outmost importance in lower extremity arterial interventions. Size optimization maximizes endothelial and balloon wall contact, thus reducing endothelial damage. This opposition is also the key for drug delivery. ${ }^{[11-14]}$ Moreover, the access site preference and arterial anatomy assessment for tortuosity and angulation and varying pathologies affect procedural outcomes in terms of a mandatory shift in balloon sizing and support catheters, wires, and access sites. ${ }^{[14,15]}$ Even, a more extensive procedural shift to atherectomy may be necessary intraoperatively. ${ }^{[15]}$ These intraoperative shifts may lead to more extensive endothelial damage with inadequate drug delivery and finally an increased risk of restenosis. ${ }^{[15-18]}$ Pre-procedural decision making and practice with $3 \mathrm{D}$ printing technology may overcome those mentioned drawbacks and increase success rates with optimization of outcomes. In our study, we observed that operators tended to select longer and larger balloons, which as mentioned above, and this may have adversely affected the outcomes. As for vascular access sites, there was an optional change in five patients in addition to a therapeutic modality shift (from intervention to medical) in one patient. Change in catheter and wire was observed in eight patients.

On the other hand, for informative purposes, we should mention that the technology has also certain drawbacks. The materials used and printing technology itself adds an additional cost to treatment modality. The real-life experience may deviate from the pre-procedural study and may affect the success of 
the procedures, such as unexpected complications that almost never happens in in vitro models. The operator should be also involved in the pre-procedural printing process and examine both radiological images and 3D-printed models by himself.

This study is retrospective in nature that may lead to bias. A study design using pre-procedural planning with the model and comparing it with the actual, as in prospective studies, would provide more robust findings. In addition, this study is a single-center study with a small sample size, and the results cannot be generalized to the overall population. The cost of the model is also another limitation. Each model takes $6 \mathrm{~h}$ to print and costs around $€ 400$. The model may not be cost-effective currently; however, with the wide use of the models, the costs may decrease. Moreover, the method may also prevent further interventions by enabling a more accurate sizing.

In conclusion, the use of 3D print technology in complex interventions of lower extremity arterial disease is a promising and encouraging field of medicine and engineering. It may help medical professionals in better understanding of the anatomy of lower extremity arteries and the pathological changes. This, in turn, aids in more accurate access site preference and catheter and balloon sizing, thereby, resulting in an optimal balloon and endothelial opposition. The physical hollow models may be employed for educational purposes, since they allow an unlimited practice opportunity. As a basic rule, "practice brings experience" and, therefore, more the models being used, more skillful and experienced operators would be. The technology itself may act as an inevitable part of trainee education and may decrease inter-operator variability. In the future, a combination of 3D printing software technology and virtual practice may provide opportunities in virtual modeling.

\section{Acknowledgements}

We would like to thank Dr. Kevser Setenay Dinçer Öner (Osmangazi University) for performing statistical analysis of the study.

\section{Declaration of conflicting interests}

The authors declared no conflicts of interest with respect to the authorship and/or publication of this article.

\section{Funding}

All expenses of the study were covered by the BTECH Company where the Osman Tunç is an employed engineer.

\section{REFERENCES}

1. Byrne N, Velasco Forte M, Tandon A, Valverde I, Hussain T. A systematic review of image segmentation methodology, used in the additive manufacture of patient-specific 3D printed models of the cardiovascular system. JRSM Cardiovasc Dis 2016;5:2048004016645467.

2. Anwar S, Singh GK, Miller J, Sharma M, Manning P, Billadello JJ, et al. 3D Printing is a Transformative Technology in Congenital Heart Disease. JACC Basic Transl Sci 2018;3:294-312.

3. Lee M, Moharem-Elgamal S, Beckingham R, Hamilton M, Manghat N, Milano EG, et al. Evaluating 3D-printed models of coronary anomalies: a survey among clinicians and researchers at a university hospital in the UK. BMJ Open 2019;9:e025227.

4. Wang DD, Gheewala N, Shah R, Levin D, Myers E, Rollet $\mathrm{M}$, et al. Three-Dimensional Printing for Planning of Structural Heart Interventions. Interv Cardiol Clin 2018;7:415-23.

5. Gocer H, Durukan AB, Tunc O, Naseri E, Ercan E. A Novel Method to Adjust Saphenous Vein Graft Lengths Using 3D Printing Models. Heart Surg Forum 2020;23:E135-E139.

6. Göçer H, Durukan AB, Tunç O, Naseri E, Ercan E. Evaluation of $3 \mathrm{D}$ printed carotid anatomical models in planning carotid artery stenting. Turk Gogus Kalp Dama 2020;28:294-300.

7. Govsa F, Yagdi T, Ozer MA, Eraslan C, Alagoz AK. Building 3D anatomical model of coiling of the internal carotid artery derived from CT angiographic data. Eur Arch Otorhinolaryngol 2017;274:1097-102.

8. Binder TM, Moertl D, Mundigler G, Rehak G, Franke M, Delle-Karth G, et al. Stereolithographic biomodeling to create tangible hard copies of cardiac structures from echocardiographic data: in vitro and in vivo validation. J Am Coll Cardiol 2000;35:230-7.

9. Aboyans V, Ricco JB, Bartelink MEL, Bjorck M, Brodmann M, Cohnert T, et al. 2017 ESC Guidelines on the Diagnosis and Treatment of Peripheral Arterial Diseases, in collaboration with the European Society for Vascular Surgery (ESVS). Rev Esp Cardiol (Engl Ed) 2018;71:111.

10. Kappanayil M, Koneti NR, Kannan RR, Kottayil BP, Kumar K. Three-dimensional-printed cardiac prototypes aid surgical decision-making and preoperative planning in selected cases of complex congenital heart diseases: Early experience and proof of concept in a resourcelimited environment. Ann Pediatr Cardiol 2017;10:11725.

11. Mirabella T, MacArthur JW, Cheng D, Ozaki CK, Woo YJ, Yang M, et al. 3D-printed vascular networks direct therapeutic angiogenesis in ischaemia. Nat Biomed Eng 2017;1:0083.

12. Goudie C, Kinnin J, Bartellas M, Gullipalli R, Dubrowski A. The Use of 3D Printed Vasculature for Simulation-based Medical Education Within Interventional Radiology. Cureus 2019; 11:e4381. 
13. O'Reilly MK, Reese S, Herlihy T, Geoghegan T, Cantwell $\mathrm{CP}$, Feeney RN, et al. Fabrication and assessment of 3D printed anatomical models of the lower limb for anatomical teaching and femoral vessel access training in medicine. Anat Sci Educ 2016;9:71-9.

14. Shanmugasundaram M, Murugapandian S, Truong HT, Lotun K, Banerjee S. Drug-coated balloon in peripheral artery disease. Cardiovasc Revasc Med 2019;20:338-43.

15. McCallum JC, Wyers MC, Soden PA, Eidt JF, Guzman RJ, Schermerhorn ML, et al. Vascular fellow and resident experience performing infrapopliteal revascularization with endovascular procedures and vein bypass during training. $\mathbf{J}$ Vasc Surg 2018;68:1533-7.
16. Almasri J, Adusumalli J, Asi N, Lakis S, Alsawas M, Prokop LJ, et al. A systematic review and meta-analysis of revascularization outcomes of infrainguinal chronic limb-threatening ischemia. Eur J Vasc Endovasc Surg 2019;58:S110-S119.

17. Khoury MK, Rectenwald JE, Tsai S, Kirkwood ML, Ramanan $\mathrm{B}$, Timaran $\mathrm{CH}$, et al. Outcomes after open lower extremity revascularization in patients with critical limb ischemia. Ann Vasc Surg 2020;67:417-24.

18. Otsuka F, Nakano M, Sakakura K, Ladich E, Kolodgie FD, Virmani R. Unique demands of the femoral anatomy and pathology and the need for unique interventions. J Cardiovasc Surg (Torino) 2013;54:191-210. 